\title{
Dendroecology in young stands: case studies from jack pine in northern lower Michigan
}

\author{
Carolyn A. Copenheaver ${ }^{*}$, Marc D. Abrams \\ 203 Forest Resources Laboratory, School of Forest Resources, The Pennsylvania State University, University Park, PA 16802, USA
}

Received 28 September 2002; received in revised form 2 December 2002; accepted 12 January 2003

\begin{abstract}
Eight jack pine (Pinus banksiana) stands in northern lower Michigan were sampled to evaluate the potential of dendroecological methods for studying stand dynamics with young trees. At each stand, a minimum of 20 dominant and codominant trees were cored, and at two stands additional recruitment data were collected. The cores were all cross-dated and measured. The raw ring widths were used to identify growth suppressions and releases within the individual chronologies. Standardized master chronologies were developed, and the residual master chronology from each stand was correlated with temperature and precipitation to identify significant dendroclimatic relationships that may reduce the ecological signal in the tree-ring record. There were no important dendroclimatic relationships at any of the eight stands; therefore, the tree-ring record was largely a reflection of stand development. At all stands, suppression periods were more common than release events because all of the stands were composed of open-grown jack pine that had initial high rates of growth. The jack pine plantations had synchronous canopy closure (as evidenced by suppression), but the naturally regenerated stands had asynchronous canopy closure. Thus, the master chronologies were useful for identifying common stand-level growth patterns within plantations, but the individual tree chronologies were more useful within the naturally regenerated stands. One of the limitations of calculating suppression events in young trees was that the first and last 10 years of the chronology were excluded because of the equations used to calculate suppression events; therefore, any changes in growth pattern during these periods had to be visually identified. By combining quantitatively determined suppression events with recruitment data and visual interpretation of the chronologies, reconstruction of stand development events, canopy closure, thinning treatments and subsequent canopy re-closure, and changes in species composition associated with stand development were all identified within the tree-ring record. Thus, there is great potential for dendroecological studies in young trees to improve our understanding of the early stages of stand development.
\end{abstract}

(C) 2003 Elsevier Science B.V. All rights reserved.

Keywords: Canopy closure; Dendroecology; Michigan; Jack pine; Dendrochronology

\footnotetext{
* Corresponding author. Present address: Forestry Department, Virginia Polytechnic Institute and State University, 228C Cheatham Hall, Blacksburg, VA 24061, USA. Tel.: +1-540-961-4031; fax: +1-540-961-3330.

E-mail address: ccopenhe@vt.edu (C.A. Copenheaver).
}

\section{Introduction}

Dendroecology was developed as a sub-field within dendrochronology by forest ecologists interested in using tree-ring patterns to recreate stand dynamics (Fritts and Swetnam, 1989). The method has proven to be valuable for reconstructing historical disturbance 
regimes and identifying declines in growth resulting from environmental change. Dendroecology has been used to identify the frequency of insect outbreaks, fire, windthrow, anthropogenic disturbance, and forest decline (Abrams and Black, 2000; Brown et al., 2000; Abrams et al., 2001; Rolland et al., 2001). One of the main advantages of dendroecology is that it provides one of the longest forest history records on an annual scale. The length of the record is particularly important when researching disturbances that have a long return interval. Dendroecology has therefore focused its research efforts on long-lived species and on old-growth stands, because these sites provide the longest tree-ring records.

Many dendroecologists identify ecologically important tree-ring patterns in mature trees to study oldgrowth forest gap dynamics. One of the most useful techniques developed within this research area was the identification of release events (also known as "pointer intervals") in tree-ring growth (Lorimer and Frelich, 1989; Schweingruber et al., 1990; Nowacki and Abrams, 1997). Release events, periods of aboveaverage radial growth, represent a post-disturbance environment when residual trees had increased resource availability and responded with increased tree-ring growth. Three main techniques exist for identifying release events in tree-ring patterns. The simplest method involves visually identifying increased growth from stand chronologies (Cherubini et al., 1996). A similar method involves visually identifying release events and then comparing the ring width from these periods of high growth to periods of average growth (Arquillière et al., 1990). A more quantitative alternative uses a radial growth averaging criteria based on the percent increase in a running average of tree-ring widths over a sufficient time period to distinguish a disturbance-related release (Abrams and Orwig, 1996; Abrams et al., 1998). The studies that used this quantitative method have identified a need to differentiate between understory and overstory release criteria because understory trees have exhibited greater growth releases (due to prior suppression and younger age) than overstory trees (Nowacki and Abrams, 1997; Abrams et al., 1999). Thus, age-related differences in tree response to environmental change may exist. However, the same techniques can be employed to look at disturbance in young and old trees; but the criteria used to identify events may need to be adjusted.
The purpose of this study was to identify whether the methods developed for old-growth dendroecological studies may be equally well-suited for research in younger stands. It has been suggested that juvenile growth in trees is more erratic than mature growth, because immature growth responds to more environmental cues. However, within the field of dendrochronology, it has long been recognized that multiple environmental variables influence tree-ring growththe variable of interest is the signal and the other variables are noise (Fritts, 1976). The objective of data analysis in dendrochronology is to maximize the signal and minimize the noise. Dendroecologists have developed a number of techniques for maximizing the signal resulting from stand dynamics (including the release methodologies discussed above). Therefore, if these same techniques are applied to young stands, it should be possible to screen the noise and identify the ecological signal within the tree rings.

The suppression events, or reductions in radial growth, associated with canopy closure are the most important dendroecological signals to detect in young stands. Within dendroecology, identification of suppression periods has mostly come from research on insect outbreaks, stand demographic studies, and forest decline. Research in these fields has largely relied upon visual identification of periods of suppression or comparisons between average ring widths from known periods of insect outbreaks and non-outbreak periods (Levanic and Čufar, 1995; Naidoo and Lechowicz, 2001). Although a few quantitative techniques for identifying periods of suppression have been developed for studies of insect outbreaks and tree decline (Weber, 1997), the growth patterns following an insect outbreak are different than the patterns associated with canopy closure, because canopy closure causes a gradual decline in growth as opposed to the instantaneous reductions in growth that follow a large-scale defoliation. Therefore, the quantitative definition of a suppression used by Kelly and Larson (1997) in their old-growth demographic research in Canada may be the most suitable technique for identifying suppressions associated with canopy closure, because the expected growth patterns should be similar. Kelly and Larson (1997) define a suppression event as a reduction in average ring width of at least $50 \%$ in a comparison of two consecutive 10 -year periods. This is essentially the opposite definition of a release event. 
The expected growth patterns for canopy closure (an initial high growth rate followed by a decrease in growth as the canopy closes (Oliver and Larson, 1996)) are also the standard growth patterns of all trees as they age. Therefore, care must be exercised when interpreting growth patterns (Zedaker et al., 1987). This study includes a comparison of several methods of data interpretation to identify methods most appropriate for isolating stand development patterns from other influences on the tree-ring record. Individual tree-ring chronologies, standardized master chronologies, calculated suppression and release events, and recruitment data are all evaluated for their effectiveness in dendroecological studies in young stands.

To evaluate the success of using dendroecological methods to study stand dynamics in young trees, many young stands were required. The disturbance history of northern lower Michigan (frequent fires and frequent harvesting) created an ideal study site because many young jack pine stands were available (Whitney, 1987). Jack pine is shade intolerant, which ensured that the trees would be open-grown rather than released from decades of suppression in the understory (Rudolph and Laidly, 1990). Because most of the jack pine stands were on xeric, sandy soils, precipitation and temperature were also potential limitations to radial growth. These influences were assessed so that the climatic signal could be separated from the ecological signal within the tree-ring record.

By applying, modifying, and testing several existing techniques used by old-growth dendroecologists for research in younger stands, this study will open a new research area for dendroecologists. The traditional reliance on old-growth stands for dendroecological study sites has limited the location and species that can be studied. It is hoped that these new techniques will be applied in younger stands to improve our understanding of the early stages of stand development in a variety of forested ecosystems.

\section{Methods}

\subsection{Study area}

Glacial features such as outwash plains, former lake basins, and moraines are common in northern lower
Michigan and determine the distribution of the three dominant forest communities (Farrand and Eschman, 1974; Barnes and Wagner, 1996). The pine community exists on sandy, excessively well-drained glacial outwash plains; the northern hardwoods community occupies more mesic moraine and outwash deposits; and the conifer bog and swamp community occupies former glacial lake basins. The pine community is frequently disturbed and dominated by short-lived species such as jack pine (Pinus banksiana) (Whitney, 1987). The jack pine stands used for this study were scattered over northern lower Michigan (Fig. 1). Alpena, Baldwin, Grayling, Gaylord, Kalkaska, Houghton Lake, and Mio were on Grayling sand, and Pellston was on Rubicon sand (Veatch et al., 1931; Buchanan, 1985; Tardy, 1991; Werlein, 1998).

The climate in Michigan's lower peninsula is strongly influenced by Lake Michigan to the west and Lake Huron to the east. The most extreme temperatures occur in the interior of the peninsula, and the temperatures near the shore are moderated by the Great Lakes (Denton and Barnes, 1987). The western half of the peninsula receives more precipitation than the eastern half because the prevailing winds travel from west to east off Lake Michigan (Barnes and Wagner, 1996).

\subsection{Dendrochronology methods}

Eight young jack pine stands were located in northern lower Michigan. Naturally regenerated jack pine on xeric sites can take several years to occupy all growing space; therefore, we selected a mixture of naturally regenerated stands with closed canopies and plantations where stocking levels were sufficient that the stands reached canopy closure at a younger age than the naturally regenerated stands. Within each stand, a minimum of 20 trees were cored from two radii at $0.5 \mathrm{~m}$ in height (Table 1 ). Only dominant and co-dominant trees were selected for coring which means the intermediate and suppressed trees were not included in the sampling. Cores were dried and glued onto core mounts (Phipps, 1985). All cores were sanded to reveal cellular structure and help identify false and light rings, which are particularly common in jack pine (Volney and Mallett, 1992). The cores were visually cross-dated within each stand by identifying narrow rings (Yamaguchi, 1991). During cross-dating, 


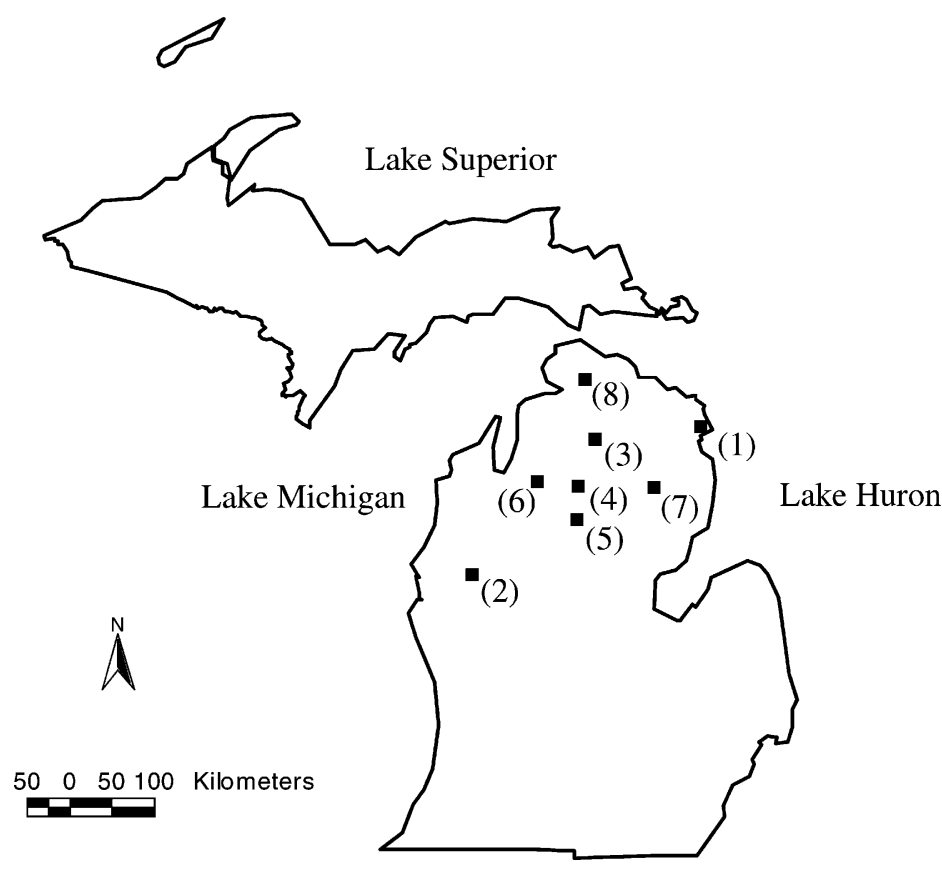

Fig. 1. The study sites were all located in Northern lower Michigan. The eight sites were: (1) Alpena, (2) Baldwin, (3) Gaylord, (4) Grayling, (5) Houghton Lake, (6) Kalkaska, (7) Mio, and (8) Pellston.

decade years were marked to assist measuring accuracy. All cores were measured to $0.002 \mathrm{~mm}$ using the Unislide "TA" Tree-Ring Measurement System (Velmex Inc., Bloomfield, NY). Each stand was crossdated a second time using the COFECHA program available within the Dendrochronology Program Library (ftp://ftp.cricyt.edu.ar/users/dendro/). Any dating problems identified by COFECHA were reexamined and errors were corrected.

\subsection{Dendroecological analysis}

To identify canopy closure and subsequent canopy openings, suppression and release events were identified for each tree based on the raw ring widths. Periods of moderate and major suppression were identified by 50 and $100 \%$, respectively, decreases in radial growth based on a comparison of the average raw ring width from the previous 10 years to the following 10 years.

Table 1

The eight jack pine stands were located in northern lower Michigan ${ }^{\mathrm{a}}$

\begin{tabular}{llllllc}
\hline Site & Latitude and longitude & Elevation (m a.s.l.) & Slope & Chronology span & Number of trees & Stand origin \\
\hline Alpena & $45^{\circ} 04^{\prime} \mathrm{N}, 83^{\circ} 34^{\prime} \mathrm{W}$ & 210 & Level & $1946-1996$ & 20 & Plantation \\
Baldwin & $43^{\circ} 54^{\prime} \mathrm{N}, 85^{\circ} 51^{\prime} \mathrm{W}$ & 254 & Rolling & $1924-1996$ & 24 & Natural \\
Gaylord & $45^{\circ} 02^{\prime} \mathrm{N}, 84^{\circ} 40^{\prime} \mathrm{W}$ & 411 & Level & $1954-1996$ & 23 & Plantation \\
Grayling & $44^{\circ} 39^{\prime} \mathrm{N}, 84^{\circ} 42^{\prime} \mathrm{W}$ & 347 & Level & $1916-1996$ & 21 & Plantation \\
Houghton Lake & $44^{\circ} 19^{\prime} \mathrm{N}, 84^{\circ} 53^{\prime} \mathrm{W}$ & 346 & Level & $1920-1996$ & 21 & Natural \\
Kalkaska & $44^{\circ} 44^{\prime} \mathrm{N}, 85^{\circ} 10^{\prime} \mathrm{W}$ & 317 & Level & $1939-1996$ & 21 & Plantation \\
Mio & $44^{\circ} 40^{\prime} \mathrm{N}, 84^{\circ} 08^{\prime} \mathrm{W}$ & 293 & Rolling & $1930-1996$ & 20 & Natural \\
Pellston & $45^{\circ} 15^{\prime} \mathrm{N}, 84^{\circ} 12^{\prime} \mathrm{W}$ & 218 & Level & $1938-1996$ & 20 & Natural \\
\hline
\end{tabular}

${ }^{a}$ All trees were cored twice at $0.5 \mathrm{~m}$ and cross-dated for accurate dating. Thus, the chronology span represents the stand age from when the trees reached $0.5 \mathrm{~m}$. Some of the naturally regenerated stands had a minor hardwood or white pine component, but the plantations were pure jack pine. 
Moderate and major release events were identified by 50 and $100 \%$ increases in radial growth, respectively, based on the same comparison of 10-year running averages of raw ring width. Some dendroecologists, in their work in old growth, calculate major release events based on 15-year averages (Nowacki and Abrams, 1997). However, many of the trees in this study were less than 50 years of age and using a 15 -year average to calculate major suppression and release events would have eliminated $60 \%$ of the chronology (the first 15 years and the last 15 years); therefore, the 10-year average was used to calculate both the moderate and major periods of suppression and release.

Standardized master chronologies were constructed for each stand. Depending upon the growth pattern of each tree, either a negative exponential curve or the average tree-ring width was used to detrend the raw ring widths in the ARSTAN program available within the Dendrochronology Program Library. The detrended raw ring widths were averaged for each stand to create stand master chronologies. Because these chronologies were being used to identify visual changes in tree-ring growth, the high autocorrelation present in the master chronologies was not addressed.

At two stands, Houghton Lake and Mio, additional cores were collected to evaluate the usefulness of pairing recruitment data with ring width growth patterns. At both Houghton Lake and Mio, 11 point-centered quarter plots were established along two transects to randomly sample additional trees (Mueller-Dombois and Ellenberg, 1974). Within each point-centered quarter plot, the nearest tree or sapling in each of the four quarters was either cored twice or destructively sampled. These cores and cookies were then sanded and visually cross-dated using narrow indicator rings (Yamaguchi, 1991).

\subsection{Dendroclimatic analysis}

To ascertain the influence of climate on jack pine radial growth, we tested for significant relationships between tree rings and climatic variables at each stand. Stand chronologies were developed from the raw ring widths using the ARSTAN program. Raw ring widths were detrended with a negative exponential curve. If the curve was an inappropriate standardization method (according to a plot of the raw ring widths), the mean ring width was used for detrending. The detrended ring widths were averaged to create a master chronology. The standard master chronology had high autocorrelation at all eight sites; therefore, to meet the assumptions for the dendroclimatic analysis, the residual chronology (based on the average residuals from autoregressive modeling of the detrended raw ring widths) was used for all dendroclimatic analysis because the autoregressive moving average process removes the autocorrelation.

The regional precipitation and temperature data were available from the National Oceanic and Atmospheric Administration (NOAA) for all stands from 1949 to the present. Monthly temperature values were calculated by averaging daily average temperature. Monthly precipitation was calculated by summing the daily values. Because the state climate district data were used rather than the local station data, missing data were not a problem. PRECON 5.17C (DendroPower, Tucson, AZ) was used to calculate correlations between the climatic variables and the residual treering chronologies. Correlations were calculated from May of the previous growing season to August of the current growing season to account for any lag in climatic influence (Fritts, 1976).

\section{Results}

More trees evaluated in this study contained suppression events than release events (Table 2). The proportion of trees experiencing suppression events varied from stand to stand depending on whether the stands had reached full canopy closure and on the sensitivity of the tree-ring record. A number of trees had neither suppressions nor releases, which indicated that the canopies at these sites had not fully closed.

Evaluating the presence of suppression events within the tree-ring record elucidated some of the stand development patterns in young jack pine stands. At some stands, trees experienced synchronized suppression periods within the same decade (Fig. 2). This pattern was most common in the plantation sites, where initial uniform tree spacing contributed to a common canopy closure date. In other plantations, trees experienced two stand-wide suppression periods. The first period was associated with canopy closure and the second period was associated with a second 
Table 2

At most sites a majority of trees experienced growth suppressions that coincided with stand closure; however, because the stands were relatively young, few trees experienced growth releases ${ }^{\mathrm{a}}$

\begin{tabular}{|c|c|c|c|c|}
\hline Site & $\begin{array}{l}\text { Trees with neither } \\
\text { suppressions or releases (\%) }\end{array}$ & $\begin{array}{l}\text { Trees with only } \\
\text { releases }(\%)\end{array}$ & $\begin{array}{l}\text { Trees with only } \\
\text { suppressions (\%) }\end{array}$ & $\begin{array}{l}\text { Trees with both suppressions } \\
\text { and releases }(\%)\end{array}$ \\
\hline Alpena & 10 & 0 & 90 & 0 \\
\hline Baldwin & 50 & 4 & 38 & 8 \\
\hline Gaylord & 17 & 0 & 83 & 0 \\
\hline Grayling & 55 & 9 & 32 & 5 \\
\hline Houghton Lake & 24 & 0 & 71 & 5 \\
\hline Kalkaska & 48 & 0 & 33 & 19 \\
\hline Mio & 50 & 10 & 40 & 0 \\
\hline Pellston & 16 & 16 & 42 & 26 \\
\hline
\end{tabular}

${ }^{\text {a }}$ Suppressions were identified as a decrease in growth of at least $50 \%$ based on a 10 -year average of ring width and releases were identified as in increase in growth of at least $50 \%$ based on a 10 -year average of ring width.

canopy closure following a thinning treatment (Fig. 3). In contrast to the plantation sites, some naturally regenerated stands showed greater variability in their suppression periods. Although the common growth pattern of decreasing raw ring width with time was

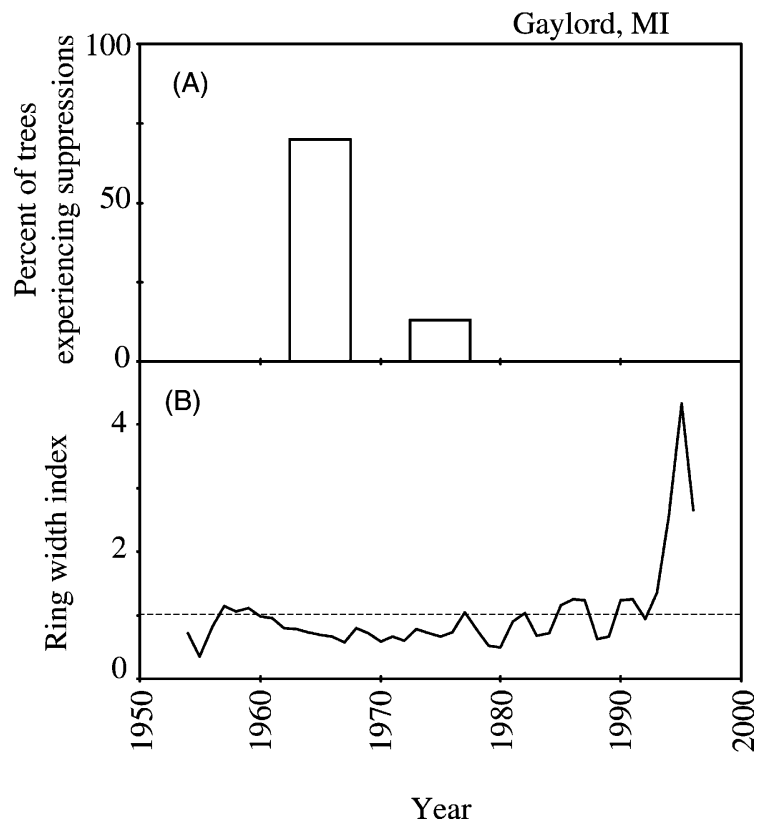

Fig. 2. The jack pine plantation from Gaylord, Michigan experienced variations in tree-ring growth over time. (A) A closely synchronized suppression period in the 1960s was associated with canopy closure. A suppression was defined as at least a 50\% decrease in ring width over a 10-year period. (B) The RWI (based on standardized ring widths of 23 jack pine) showed a steep increase in growth in 1993 as a result of a thinning treatment. identified in all trees at these sites, the actual timing of suppression (representing canopy closure) appeared at different time periods throughout the stand (Fig. 4). Another pattern identified in naturally regenerated jack pine stands was the absence of suppression events.

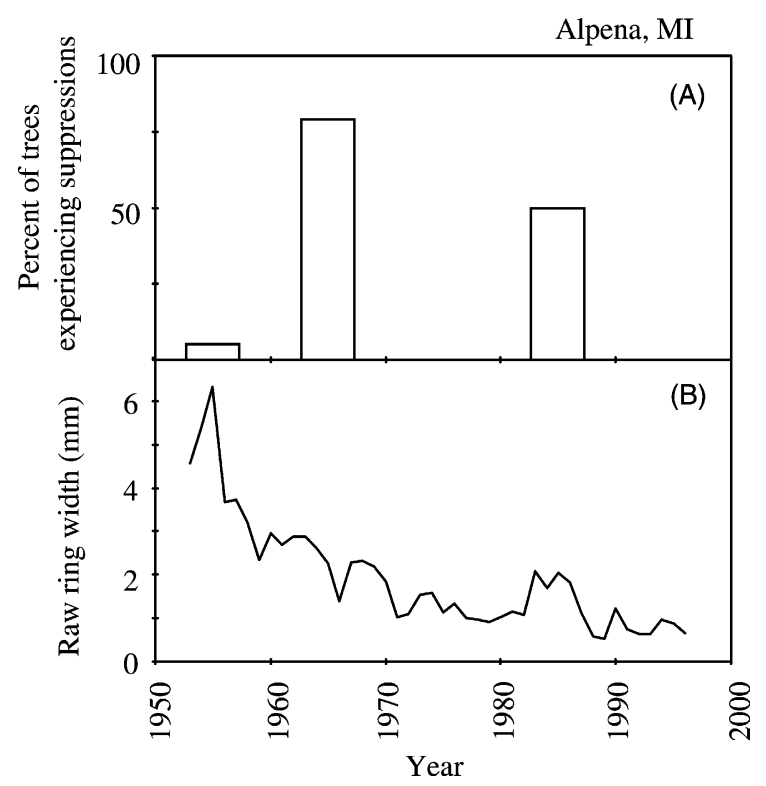

Fig. 3. (A) The jack pine plantation at Alpena, Michigan had two main periods of suppression. The reduction in growth in the 1960s represented canopy closure and the canopy closed a second time in 1980s following a thinning treatment. (B) The individual tree chronology shows both the decline in growth associated with canopy closure and the release in growth and subsequent suppression from the thinning treatment. 


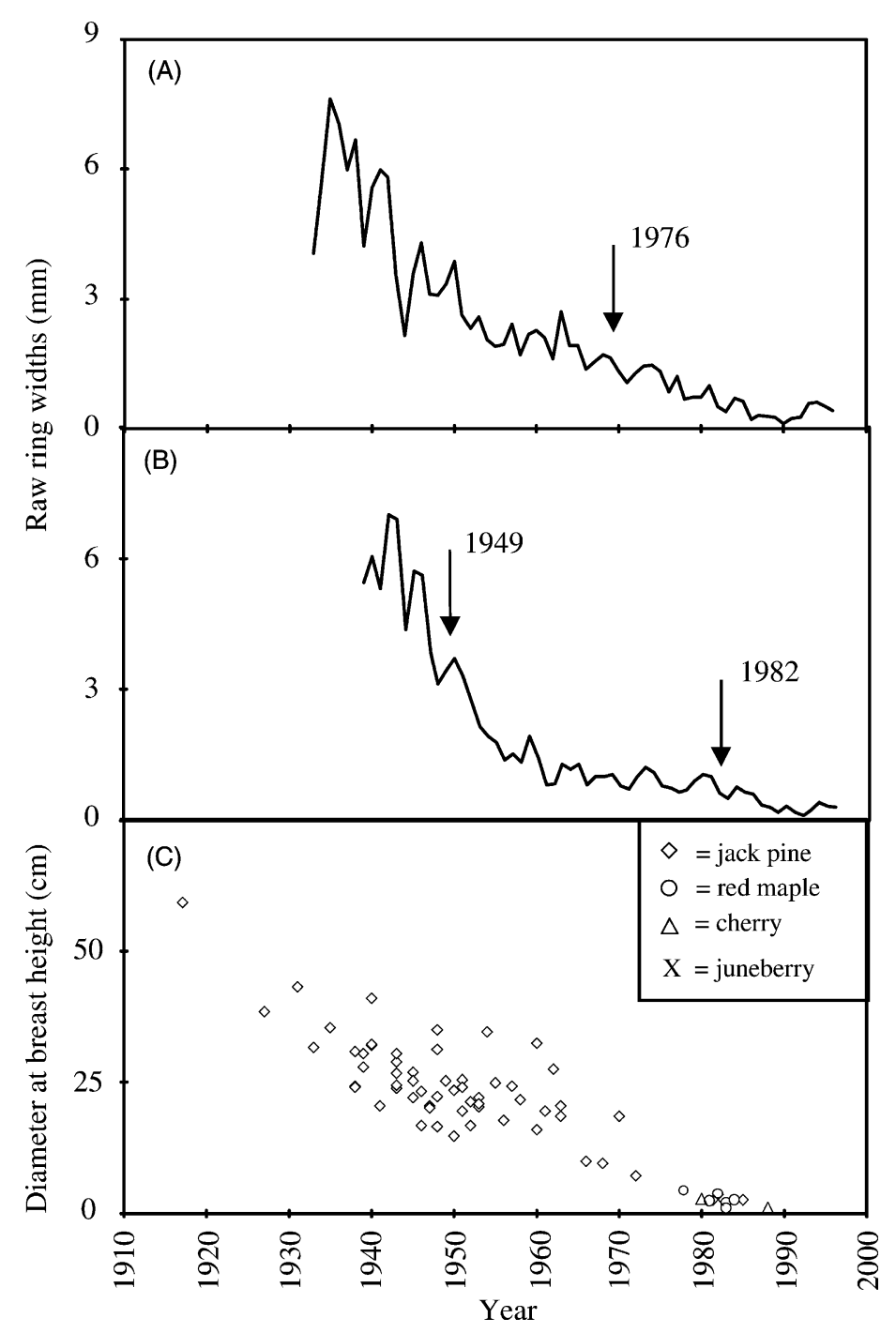

Fig. 4. Coupling ring widths with recruitment data allows patterns of stand dynamics to be seen. (A) A jack pine tree at Houghton Lake, Michigan exhibited the expected decrease in ring width with increasing age. The arrow marks a suppression event defined by a decrease in average ring width over a 10-year period of at least 50\%. (B) A different jack pine from the same stand had different suppression periods (1949 and 1982) because the suppression events in the naturally regenerated stands were unsynchronized. (C) Jack pine was the only species to successfully enter the stand until canopy closure when hardwood species established in the understory.

In some of the youngest stands, many of the trees continued to grow at a rapid rate and therefore had experienced neither suppression nor release (Table 2).

The timing of release and suppression events in younger stands was crucial to their detection with the quantitative analysis. In the calculation of the release and suppression events, the first and last 10 years of the chronology were essentially "blind spots" for detecting release or suppression events, because there were no years to contrast with these growth periods. Therefore, any release or suppression events that occurred within these blind spots could only be identified by visual analysis. For example, both Alpena and Gaylord were plantation sites that had been thinned (Figs. 2 and 3). At Alpena, the thinning occurred in 1982, and $50 \%$ of the trees experienced a moderate 
suppression in the mid-to-late 1980s as the reopened canopy closed. In contrast, at Gaylord, the thinning occurred in 1993, which was in the "blind spot" for release calculations; therefore, this event remained undetected as a release event, although it was clearly visible in the standardized master chronology (Fig. 2B).

Only weak dendroclimatic relationships were identified for the eight jack pine stands. Alpena had no significant correlations with temperature or precipitation during the 16-month dendroclimatic year. Baldwin had a negative significant correlation (95\% confidence) between ring width index (RWI) and May temperature $(r=-0.40)$. Gaylord had a positive significant correlation between RWI and March temperature $(r=0.32)$ and August precipitation $(r=0.39)$, and a negative significant correlation between RWI and December precipitation $(-0.41)$. Grayling had a negative significant correlation between RWI and January temperature $(r=-0.32)$, and a positive significant correlation between RWI and April temperature $(r=0.32)$. Houghton Lake had a negative significant correlation between RWI and the previous October's precipitation $(r=-0.31)$. Kalkaska had a negative significant correlation between RWI and December's temperature $(r=-0.30)$. Mio had a negative significant correlation between RWI and temperature in the previous May $(r=-0.31)$, December $(r=-0.41)$, and January $(r=-0.30)$, and a positive significant correlation between RWI and July's precipitation $(r=0.43)$. Pellston had no significant correlations between treering growth and climate.

\section{Discussion}

The methods developed by dendroecologists for studying stand dynamics in old-growth forests can be readily adapted for research in young stands. Because there are fundamental differences in the ecologically significant growth patterns in young stands vs old-growth stands, some of the methods (i.e., release events) that have proven most useful in old-growth forests were not useful in the case studies of young jack pine stands. However, other existing dendroecological methods worked well to identify the ecologically significant patterns. One conclusion from this study was that in young stands, it was important to combine several dendroecological methods because the shortness of the stand chronology reduced the effectiveness of the methods for identifying some of the important signals. However, a combination of several techniques insured that important patterns would not be missed. Even with these limitations, dendroecology was a useful tool for understanding dynamics in young jack pine stands.

For detecting canopy closure in the young jack pine stands, master chronologies were useful at the plantations, but the individual tree chronologies were more suitable at the naturally regenerated sites. The uniform initial spacing of the plantations resulted in a common canopy closure time, identified by the synchronized suppression events (Fig. 2), which made the stand master chronology a useful tool for identifying common stand development patterns because the influence of tree age was removed from the chronology (Fritts, 1976). However, at the naturally regenerated stands, canopy closure was not synchronized across the stand and instead followed the gradual "filling in" of gaps described for jack pine on xeric sites (Gauthier et al., 1993). This asynchronous canopy closure could only be identified on individual tree chronologies (Fig. 4). Therefore, at sites where an asynchronous canopy closure is expected or where the canopy closure pattern is unknown, individual tree chronologies should be used rather than master chronologies.

Although most old-growth studies use a single method for identifying radial growth suppressions (visual or a variation on the quantitative techniques developed by Nowacki and Abrams (1997)), in younger stands the only successful method was to combine both visual and quantitative techniques. Because the chronologies were so short, the quantitative techniques only worked for the middle sections of the chronology, and any changes in ring width growth at the beginning or end of the chronology had to be identified visually from the individual tree chronologies or from the master chronology (Figs. 2 and 3). One technique used in Fagus grandifolia var. mexicana for identifying suppression periods from medium-length chronologies (less than 100 years) that reduced the "blind spots" at the beginning and end of the chronologies was to define suppression periods as years in which the raw ring width was below a pre-designated level $(<0.8 \mathrm{~mm})$ for at least 4 years (Willimas-Linera et al., 2000). However, establishing a designated level of suppression will vary from 
species to species and stand to stand. Thus, identifying this pre-designated level will require additional analysis and fieldwork. For stands and species where a designated suppression level has already been defined, using Willimas-Linera et al.'s (2000) method would allow identification of suppression events to be exclusively quantitative; however, in sites where this preliminary research has not been completed, it is best to combine the visual identification of suppression events with the quantitative technique developed by Nowacki and Abrams (1997).

In many old-growth studies, competition among species was inferred by comparing the duration of suppression periods (Cho and Boerner, 1995; Abrams and Orwig, 1996; Lusk and Smith, 1998). Some species endured suppressed growing conditions longer than others, which gave them a competitive advantage in low-light growing conditions. Using the duration of suppression periods to understand species competitive differences did not work in young stands because the span of the chronology was too short. However, pairing recruitment data with ring width chronologies of dominant trees identified competitive differences between species (Fig. 4). At Houghton Lake, jack pine demonstrated continuous recruitment from the 1920s through the 1980s. During this period, the open conditions of the site allowed the quick-growing jack pine to out-compete any other species; therefore, no other species successfully established until the late 1970s. By the 1970s, some parts of the canopy were beginning to close (as indicated by the suppression within the jack pine chronologies, Fig. 4A). The closed canopy created an understory that was shaded enough to allow hardwoods to out-compete the quickgrowing, but shade-intolerant jack pine (Rudolph and Laidly, 1990; Fig. 4C). Thus, in young stands, although comparing duration of suppression was not a successful technique, combining ring width chronologies with recruitment data allowed species competitive differences to be seen.

One aspect of dendroecology in young stands that this study was unable to address was the development of techniques for differentiating between climatic signals and ecological signals within the tree-ring record. All eight of the study sites showed no substantial influence of climate on tree-ring growth. The few significant correlations that existed between RWI and climatic variables were not consistent from site to site, which indicated they were spurious correlations rather than meaningful relationships. The lack of climatic influence on jack pine radial growth differs from results of previous studies that have found significant relationships (Larsen and Mac Donald, 1995; Despland and Houle, 1997; Brooks et al., 1998; Hofgaard et al., 1999). Although differences in dendroclimatic responses have been identified across the range of boreal conifers (with temperature being significantly correlated to ring width in the northern portion of the range and precipitation being significantly correlated to ring width in the southern portion of the range (Hogg, 1994)), there have been no studies examining age-related dendroclimatic differences. Therefore, our lack of significant dendroclimatic relationships within a species known to respond to climate in all portions of its range leads to the hypothesis that the weak climatic influence may have resulted from the young age of the trees. However, this hypothesis would have to be fully tested further before it could be accepted.

One potential misapplication of this study would be to use the methods developed for young stands for all young trees. The case studies provided were all from shade-intolerant, open-grown jack pine. Simply transferring the methods developed for young open-grown trees onto young trees growing under existing canopies would be inappropriate. There already exist valid dendroecological methods that have been tested in a number of ecosystems for determining canopy accession dates and gap dynamics of young trees within existing stands (Lorimer et al., 1988; Orwig and Abrams, 1994, 1995; Cao and Ohkubo, 1999; Wu, 1999; Knapp and Canham, 2000). This study is not designed to replace those methods; instead, it serves to open dendroecological research to young developing stands.

In conclusion, a combination of visual interpretation of individual tree chronologies and master chronologies, quantitatively defined suppression events, and recruitment data can all contribute to an understanding of the development patterns of young stands. Oldgrowth dendroecology studies have been criticized for using static age structures because they do not accurately portray the early stand development stages (Johnson et al., 1994). The results of this study provide an alternative to exclusive reliance on old-growth stands for deciphering stand development. Using the 
techniques identified for younger stands in combination with previously developed techniques for old-growth stands should lead to a more complete understanding of stand dynamics.

\section{References}

Abrams, M.D., Black, B.A., 2000. Dendroecological analysis of a mature loblolly pine-mixed hardwood forest at the George Washington Birthplace National Monument, eastern Virginia. J. Torrey Bot. Soc. 127, 139-148.

Abrams, M.D., Orwig, D.A., 1996. A 300-year history of disturbance and canopy recruitment for co-occurring white pine and hemlock on the Allegheny Plateau, USA. J. Ecol. 84, 353-363.

Abrams, M.D., Ruffner, C.M., DeMeo, T.E., 1998. Dendroecology and species co-existence in an old-growth Quercus-Acer-Tilia talus slope forest in the central Appalachians, USA. For. Ecol. Manage. 106, 9-18.

Abrams, M.D., Copenheaver, C.A., Terazawa, K., Umeki, K., Takiya, M., Akashi, N., 1999. A 370-year dendroecological history of an old-growth Abies-Acer-Quercus forest in Hokkaido, northern Japan. Can. J. For. Res. 29, 1891-1899.

Abrams, M.D., Copenheaver, C.A., Black, B.A., van de Gevel, S., 2001. Dendroecology and climatic impacts for a relict, oldgrowth, bog forest in the Ridge and Valley Province of central Pennsylvania, USA. Can. J. Bot. 79, 58-69.

Arquillière, S., Filion, L., Gajewski, K., Cloutier, C., 1990. A dendroecological analysis of eastern larch (Larix laricina) in subarctic Quebec. Can. J. For. Res. 20, 1312-1319.

Barnes, B.V., Wagner Jr., W.H., 1996. Michigan Trees. The University of Michigan Press, Ann Arbor, MI.

Brooks, J.R., Flanagan, L.B., Ehleringer, J.R., 1998. Responses of boreal conifers to climate fluctuations: indications from treering widths and carbon isotope analyses. Can. J. For. Res. 28, 524-533.

Brown, P.M., Ryan, M.G., Andrews, T.G., 2000. Historical surface fire frequency in ponderosa pine stands in research natural areas, central rocky mountains and Black Hills, USA. Nat. Areas J. 20, 133-139.

Buchanan, D.E., 1985. Soil Survey of Lake and Wexford Counties, Michigan. USDA Soil Cons. Serv.

Cao, K.F., Ohkubo, T., 1999. Suppression and release during canopy recruitment in Fagus crenata and Acer mono in two oldgrowth beech forests in Japan. Plant Ecol. 145, 281-290.

Cherubini, P., Piussi, P., Schweingruber, F.H., 1996. Spatiotemporal growth dynamics and disturbances in a subalpine spruce forest in the Alps: a dendroecological reconstruction. Can. J. For. Res. 26, 991-1001.

Cho, D., Boerner, R.E.J., 1995. Dendrochronological analysis of the canopy history of two Ohio old-growth forests. Vegetatio 120, 173-183.

Denton, S.R., Barnes, B.V., 1987. Spatial distribution of ecologically applicable climatic statistics in Michigan. Can. J. For. Res. 17, 598-612.
Despland, E., Houle, G., 1997. Climate influences on growth and reproduction of Pinus banksiana (Pinaceae) at the limit of the species distribution in eastern North America. Am. J. Bot. 84, 928-937.

Farrand, W.R., Eschman, D.F., 1974. Glaciation of the southern peninsula of Michigan: a review. Michigan Academician 7, 31-55.

Fritts, H.C., 1976. Tree Rings and Climate. Academic Press, New York.

Fritts, H.C., Swetnam, T.W., 1989. Dendroecology: a tool for evaluating variations in past and present forest environments. Adv. Ecol. Res. 19, 111-188.

Gauthier, S., Gagnon, J., Bergeron, Y., 1993. Population age structure of Pinus banksiana at the southern edge of the Canadian boreal forest. J. Veg. Sci. 4, 783-790.

Hofgaard, A., Tardif, J., Bergeron, Y., 1999. Dendroclimatic response of Picea mariana and Pinus banksiana along a latitudinal gradient in the eastern Canadian boreal forest. Can. J. For. Res. 29, 1333-1346.

Hogg, E.H., 1994. Climate and the southern limit of the western Canadian boreal forest. Can. J. For. Res. 24, 1835-1845.

Johnson, E.A., Miyanishi, K., Kleb, H., 1994. The hazards of interpretation of static age structures as shown by stand reconstructions in a Pinus contorta-Picea engelmannni forest. J. Ecol. 82, 923-931.

Kelly, P.K., Larson, D.W., 1997. Dendroecological analysis of the population dynamics of an old-growth forest on cliff-faces of the Niagara Escarpment, Canada. J. Ecol. 85, 467-478.

Knapp, L.B., Canham, C.D., 2000. Invasion of an old-growth forest in New York by Ailanthus altissima: sapling growth and recruitment in canopy gaps. J. Torrey Bot. Soc. 127, 307-315.

Larsen, C.P.S., Mac Donald, G.M., 1995. Relations between treering widths, climate, and annual area burned in the boreal forest of Alberta. Can. J. For. Res. 25, 1746-1755.

Levanic, T., Čufar, K., 1995. Three local silver fir (Abies alba Mill.) chronologies from the Dinaric phytogeographic region of Slovenia. Dendrochronologia 13, 127-134.

Lorimer, C.G., Frelich, L.E., 1989. A methodology for estimating canopy disturbance frequency and intensity in dense temperate forests. Can. J. For. Res. 19, 651-663.

Lorimer, C.G., Frelich, L.E., Nordheim, E.V., 1988. Estimating gap origin probabilities for canopy trees. Ecology 69, 778-785.

Lusk, C.H., Smith, B., 1998. Life history differences and tree species coexistence in an old-growth New Zealand rain forest. Ecology 79, 795-806.

Mueller-Dombois, D., Ellenberg, H., 1974. Aims and Methods of Vegetation Ecology. Wiley, New York.

Naidoo, R., Lechowicz, M.J., 2001. Effects of gypsy moth on radial growth of deciduous trees. For. Sci. 47, 338-348.

Nowacki, G.J., Abrams, M.D., 1997. Radial-growth averaging criteria for reconstructing disturbance histories from presettlement-origin oaks. Ecol. Monogr. 67, 225-249.

Oliver, C.D., Larson, B.C., 1996. Forest Stand Dynamics. Wiley, New York.

Orwig, D.A., Abrams, M.D., 1994. Contrasting radial growth and canopy recruitment patterns in Liriodendron tulipifera and Nyssa sylvatica: gap-obligate versus gap-facultative tree species. Can. J. For. Res. 24, 2141-2149. 
Orwig, D.A., Abrams, M.D., 1995. Dendroecological and ecophysiological analysis of gap environments in mixed-oak understories of northern Virginia. Funct. Ecol. 9, 799-806.

Phipps, R.L., 1985. Collecting, preparing, crossdating, and measuring tree increment cores. USDI Geological Survey. Water Res. Invest. Rep. 85-4148.

Rolland, C., Baltensweiler, W., Petitcolas, V., 2001. The potential for using Larix decidua ring widths in reconstructions of larch budmoth (Zeiraphera diniana) outbreak history: dendrochronological estimates compared with insect surveys. Trees 15, 414-424.

Rudolph, T.D., Laidly, P.R., 1990. Jack pine. In: Burns, R.M., Honkala, B.H. (Eds.), Silvics of North America. USDA Forest Service Agricultural Handbook No. 654, pp. 280-291.

Schweingruber, F.H., Eckstein, D., Serre-Bachet, F., Bräker, O.U., 1990. Identification, presentation and interpretation of event years and pointer years in dendrochronology. Dendrochronologia 8, 9-38.

Tardy, S.W., 1991. Soil Survey of Cheboygan County, Michigan. USDA Soil Cons. Serv.

Veatch, J.O., Schoenmann, L.R., Millar, C.E., Shearin, A.E., 1931. Soil Survey of Oscoda County, Michigan. USDA Bur. Chem. and Soils, No. 20.
Volney, W.J.A., Mallett, K.I., 1992. Light rings and the age of jack pine trees. Can. J. For. Res. 22, 2011-2013.

Weber, U.M., 1997. Dendroecological reconstruction and interpretation of larch budmoth (Zeiraphera diniana) outbreaks in two central alpine valleys of Switzerland from 1470 to 1990 . Trees 11, 277-290.

Werlein, J.O., 1998. Soil Survey of Crawford County, Michigan. USDA Nat. Res. Cons. Serv.

Whitney, G.G., 1987. An ecological history of the Great Lakes forest of Michigan. J. Ecol. 75, 667-684.

Willimas-Linera, G., Devall, M.S., Alvarez-Aquino, C., 2000. A relict population of Fagus grandifolia var. mexicana at the Acatlan Volcano, Mexico: structure, litterfall, phenology, and dendroecology. J. Biogeogr. 27, 1297-1309.

Wu, X.Y., 1999. Growth pattern of Picea rubens prior to canopy recruitment. Plant Ecol. 140, 245-253.

Yamaguchi, D.K., 1991. A simple method for cross-dating increment cores from living trees. Can. J. For. Res. 21, 414-416.

Zedaker, S.M., Hyink, D.M., Smith, D.W., 1987. Growth declines in red spruce: are they anthropogenic or natural? J. For. 85, 34-36. 